\title{
Avaliação de diferentes fatores na remoção de remazol brilliant blue de soluções aquosas por adsorção em fibras de cana de açúcar e coco verde
}

\author{
Evaluation of different factors in the \\ removal of remazol brilliant blue from \\ aqueous solutions by adsorption in \\ sugarcane and green coconut fibers
}

Aline Merci ${ }^{1}$, Maria Inês Rezende ${ }^{1}$, Leonel Vinicius Constantino ${ }^{1}$, Suely Mayumi Obara Doi ${ }^{1}$

\footnotetext{
${ }^{1}$ Department of Biochemistry and Biotechnology, Universidade Estadual de Londrina-UEL, Londrina, Paraná, Brasil. e-mail: aline.merci@gmail.com
}

\begin{abstract}
RESUMO
As indústrias têxteis, durante o processo de tingimento, liberam uma grande quantidade de corantes na água. Além do seu efeito visual e seus impactos adversos em relação à fotossíntese e demanda química de oxigênio, muitos corantes sintéticos são tóxicos, recalcitrantes, mutagênicos e carcinogênicos. Dessa forma, novas alternativas de tratamento dos efluentes gerados, menos agressivas ao meio ambiente, de baixo custo e renováveis tem sido buscadas, como o uso de resíduos agroindustriais lignocelulósicos, como adsorventes de corantes. Neste estudo, cana-de-açúcar e fibras de coco foram estudadas quanto à capacidade de adsorver o corante Remazol Brilliant Blue BB e investigar os efeitos do tempo, $\mathrm{pH}$, quantidade de material adsorvente e concentração de corante na adsorção do corante. O melhor tempo de adsorção foi de $24 \mathrm{~h}$ para fibra de coco e $12 \mathrm{~h}$ para fibra de cana-de-açúcar. Para ambas as fibras, o pH ótimo para a adsorção do corante foi 2, e o uso de 20 g L-1 de fibra foi o mais efetivo para remover 50-200 mg L-1 de Remazol Brilliant Blue BB, com porcentagens de adsorção acima 90,50\% observados para ambas as fibras.
\end{abstract}

Palavras-chave: Corantes têxteis, adsorção e fibras lignocelulósicas.

\begin{abstract}
The textile industries, during the dyeing process, release a large amount of dyes in the water. In addition to its visual effect and its adverse impacts on photosynthesis and chemical oxygen demand, many synthetic dyes are toxic, recalcitrant, mutagenic and carcinogenic. In this way, new alternatives of treatment of the generated effluents, less aggressive to the environment, of low cost and renewable have been sought, as the use of lignocellulosic agricultural residues, like dyes adsorbents. In this study, sugar cane and coconut fibers were studied for their ability to adsorb Remazol Brilliant Blue BB dye, and the effects of time, pH, amount of adsorbent material and dye concentration on dye adsorption were investigated. The optimal adsorption time was $24 \mathrm{~h}$ for coconut fiber and $12 \mathrm{~h}$ for sugar cane fiber. For both fibers, the optimal $\mathrm{pH}$ for the adsorption of dye was 2, and the use of $20 \mathrm{~g} \mathrm{~L}^{-1}$ of fiber was the most effective for removing 50-200 mg L-1 of Remazol Brilliant Blue BB, with adsorption percentages of above $90.50 \%$ observed for both fibers.
\end{abstract}

Keywords: Textile dye, adsorption, lignocellulosic fibers.

\section{INTRODUCTION}

Synthetic dyes are extensively produced, although the actual amount is unknown, and more than ten thousand types of synthetic dyes are available to the textile industry for dyeing and screen printing. The fixation rates for these compounds is low, and approximately $30-70 \%$ of dye is hydrolyzed when disposed in bodies of water, where their concentrations are between 10 and $200 \mathrm{mg} \mathrm{L}-1$. Synthetic dyes have thermostable and photostable structures that are able to resist to microbial attack, becoming highly recalcitrant and often carcinogenic. This effluents have high rates of BOD and COD, as well as altered $\mathrm{pH}$ values and elevated levels 
of dissolved and suspended solids [1-5]. To minimize the environmental impacts, surveillance has become increasingly rigid. Consequently, industries must use appropriate and less harmful methods of treating these effluents. Many methods are used for this purpose, with ozone- and Fenton-based oxidation processes, biological, physical, chemical, and chemical-physical methods being the most widely used. An alternative technique, the adsorption method, has become popular because of its efficiency in removing stable pollutants and for its flexibility, ease of operation, the availability of processing equipment, sludge-free operation, recovery of sorbate and economic feasibility [6-12].

The adsorption process that is used to treat wastewater involves two mechanisms, namely, adsorption and ion exchange, which are influenced by several factors, such as the ratio of the dye/adsorbent contact surface area, particle size, $\mathrm{pH}$ and contact time. However, this technique can become unviable due to the high cost of the adsorbent material. An alternative would be the use of lignocellulosic agricultural residues, such as fibers of sugar cane and green coconut, which are very attractive because of their low cost, wide availability, and biodegradable properties, as well as being one of the most abundant renewable resources in the world. Agricultural wastes are lignocellulosic materials that consist of three primary structural components, namely, cellulose, hemicelluloses and lignin. These macromolecules are present in sugarcane fiber in proportions 30 , 57 and $13 \%$ and in coconut fiber coconut at $43,0.25$ and $45 \%$ [3,10,11,13-15]. The objective of this study was to evaluate the adsorption of the textile dye Remazol Brilliant Blue BB onto sugarcane and green coconut fibers and investigate the effects of time, $\mathrm{pH}$, adsorbent and dye concentration, factors that can influence the adsorption process.

\section{MATERIALS AND METHODS}

\subsection{Materials}

The textile dye used in this study was Remazol Brilliant Blue BB, which was kindly provided by Dystar Industry and Chemicals Ltd. (Londrina, Paraná, Brazil). The sugarcane bagasse fibers and coconut fibers were obtained in the Londrina region (Paraná, Brazil).

\subsection{Methods}

\subsubsection{Preparation of adsorbent materials}

The adsorbent fibrous materials were obtained sugarcane bagasse and coconut mesocarp. The green skin covering the sugarcane and coconut, as well as the internal rigid portion of the of coconut, was removed. The remaining fibrous portions were processed in a conventional blender with distilled water. Next, the obtained material was washed multiple times with distilled water until the fibers were completely cleaned. The fibers were dried in an oven with air circulation at $70^{\circ} \mathrm{C}$ for 48 hours. Finally, the fibers were ground in a knife mill, and the particles were size-separated with 48 and 65 Mesh.

\subsubsection{Determination of the percentage of adsorption and statistical analysis}

Adsorption tests were performed by adding $50 \mathrm{~g} \mathrm{~L}-1$ of the adsorbent materials into $100 \mathrm{~mL}$ of a dye solution in an Erlenmeyer flask, which was agitated on an orbital shaker at $28 \pm 2{ }^{\circ} \mathrm{C}$ and $180 \mathrm{rpm}$. The time of contact was determined in subsequent tests.

A simple filtration procedure was used to separate the adsorbent from the supernatant. The percentage of adsorption was determined by comparing the UV-Vis absorbance of the sample supernatants with the control (without added adsorbent) at a wavelength of $600 \mathrm{~nm}$ (corresponding to the greatest adsorption of the dye) according to the following equation:

$$
\% \text { Adsorption }=\left(\frac{A b s_{0}-A b s_{t}}{A b s_{0}}\right) \times 100
$$

where Abs0 is initial absorbance and the control absorbance and Abst is the sample absorbance. The experiment was conducted in triplicate. Statistical analysis was performed in Statistica version 7.0 
(STATSOFT, Oklahoma, USA), by ANOVA followed by multiple comparisons by Tukey test ( $\mathrm{p}<0.05$ ).

\subsubsection{Effect of contact time of fibers on the adsorption of Remazol Brilliant Blue BB}

The effect of the contact time between the fibers and the dye was tested after 6, 12, 24 and 48 hours using $100 \mathrm{mg} \mathrm{L}-1$ of Remazol Brilliant Blue BB and $50 \mathrm{~g} \mathrm{~L}-1$ of fiber. Sugarcane and coconut fibers with particle sizes of 48 and 65 Mesh were assayed, and the natural $\mathrm{pH}$ of the dye was used, which was previously observed to be approximately 7 .

\subsubsection{Effect of $\mathrm{pH}$ on the adsorption of Remazol Brilliant Blue BB}

The influence of $\mathrm{pH}$ on the adsorption of Remazol Brilliant Blue BB for sugarcane and coconut fibers was next assayed. The $\mathrm{pH}$ was adjusted to $1,2,3,4,5,6$ and 7 , with $\mathrm{HCl}(0.1$ and 1 mol L-1) or $\mathrm{NaOH}(0.1$ and 1 mmol L-1), using dye concentrations of $100 \mathrm{mg} \mathrm{L}-1$ and $50 \mathrm{~g} \mathrm{L-1}$ and sugarcane or coconut fibers with particle sizes of 48 and 65 Mesh, according to section 2.2.3.

\subsubsection{Effect of adsorbent concentration on the adsorption of Remazol Brilliant Blue BB}

The influence of the concentration of sugarcane and coconut fibers on the adsorption of dye was tested by varying the amount of sugarcane and coconut fibers (10, 20, 50 and $70 \mathrm{~g} \mathrm{L-1)}$ with particle sizes of 48 and 65 mesh, with the time and $\mathrm{pH}$ used according to sections 2.2.3 and 2.2.4.

\subsubsection{Effect of dye concentration on the adsorption of Remazol Brilliant Blue BB}

To study the effect of dye concentration on the adsorption by the sugarcane and coconut fibers, four Remazol Brilliant Blue BB solutions with concentrations of 50, 100, 150 and $200 \mathrm{mg} \mathrm{L}-1$ were tested. The incubation period, $\mathrm{pH}$ and adsorption values were used according to sections 2.2.3, 2.2.4 and 2.2.5.

\section{RESULTS AND DISCUSSION}

\subsection{Effect of contact time on the adsorption of Remazol Brilliant Blue BB}

Figure 1 shows that a significant amount of dye was adsorbed after 12 hours of stirring with 48 and 65 Mesh sugarcane fiber (Tukey's test, $\mathrm{p} \leq 0.05$ ) compared to the control, with adsorption percentages of $59.71 \pm 2$ $71 \%$ and $62.32 \% \pm 0.97 \%$ observed, respectively. No significant variation between grain sizes for the sugarcane was observed.

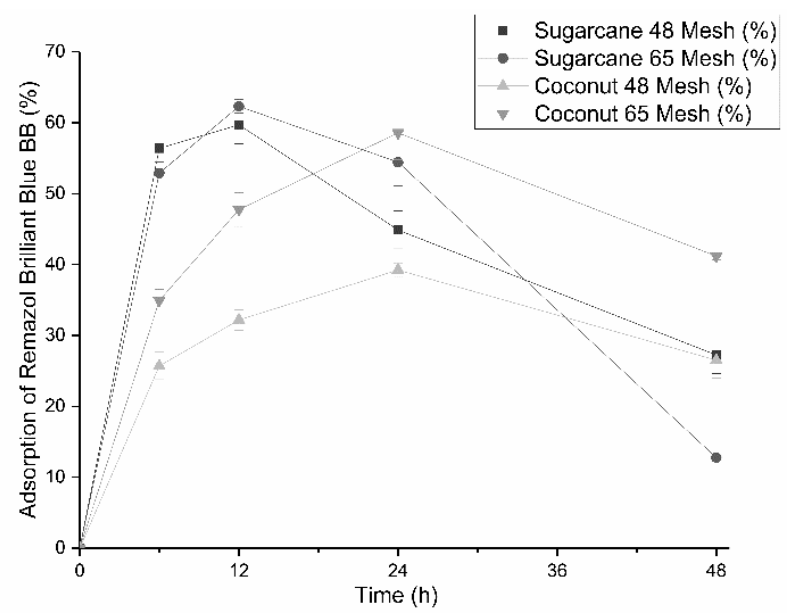

Figure 1: Effect of agitation time on the adsorption of the Remazol Brilliant Blue BB dye for sugarcane and coconut fibers with grit sizes of 48 and $65 \mathrm{Mesh}$. Mean \pm standard deviation. The test conditions were at the natural $\mathrm{pH}$ of the dye and the concentration of adsorbent $50 \mathrm{~g} \cdot \mathrm{L}^{-1}$. 
For the coconut fibers, the Remazol Brilliant Blue BB dye was significantly adsorbed at 24 hours (Tukey test, $\mathrm{p} \leq 0.05$ ). The observed adsorption with particle sizes of 48 and 65 Mesh were $39.23 \pm 0.91 \%$ and $58.58 \pm 3.81 \%$, respectively, exhibiting the highest percentage of adsorption among the coconut fiber sample tested. Among the fibers studied, sugarcane showed the maximum percentage of adsorption in half the time taken for the coconut fibers under the conditions tested in this study.

The results showed that for both fibers, a fast adsorption of the dye during the initial contact with the solution was observed. This effect has been previously observed13 and is due to the greater surface area of the adsorbent material during the initial contact.

Robinson, Chandran and Nigam [14] observed that corn cob adsorbed approximately $28 \%$ of dye in 24 hours of stirring at $28{ }^{\circ} \mathrm{C}$ when testing a mixture containing five textile dyes (Cibacron Yellow C-2R, Cibacron Red C-2G, Cibacron Blue CR, Remazol Black B, and Remazol Red RB) at a concentration of $50 \mathrm{mg}$ L-1 and with $50 \mathrm{~g} \mathrm{~L}-1$ of fiber with a particle size of $18 \mathrm{Mesh}$. By comparison, the sugarcane and coconut fibers used in this study exhibited higher percentages of adsorption at 24 hours for coconut fiber and 12 hours for sugarcane fiber.

\subsection{Effect of pH on the adsorption of Remazol Brilliant Blue BB}

The results obtained for the effect of $\mathrm{pH}$ on the adsorption of dye are shown in Figure 2. The observed adsorption of dye by coconut and sugarcane fibers was significant (Tukey's test, $\mathrm{p} \leq 0.05$ ) at $\mathrm{pH} 2$. The time used this test was based on the observed effect of contact time on adsorption for the two fibers, with 12 hours used for sugarcane and 24 hours for green coconut. The percentage adsorption for sugarcane for particle sizes of 48 and 65 Mesh was $97.41 \pm 0.10 \%$ and $97.05 \pm 3.36 \%$, respectively (Figure 2), while for coconut fibers, these values were $94.06 \pm 0.27 \%$ and $97.39 \pm 0.75 \%$, respectively. For the particle sizes studied in this work, larges differences in percentages of adsorption were not observed for sugarcane fibers. However, for the green coconut fiber, a small difference between the percentages of adsorption was observed between particle sizes assayed, with the particle size of 65 Mesh showing the highest adsorption average. This observation can be explained by the greater surface contact between the dye solution and the adsorbent fibers.

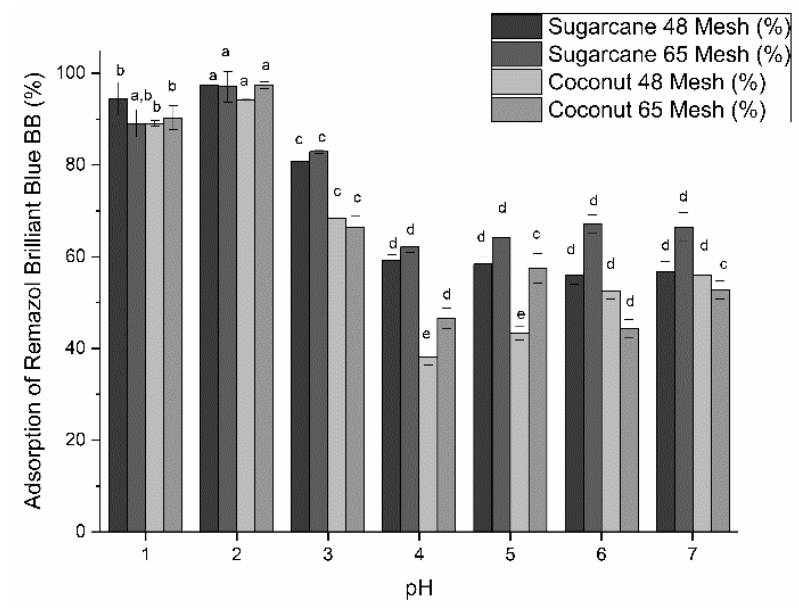

Figure 2: Effect of $\mathrm{pH}$ on adsorption of Remazol Brilliant Blue BB for sugarcane and coconut fibers with grit sizes of 48 and 65 Mesh. Means \pm standard deviation. Different letters indicate significant differences between the samples (Tukey test, $\mathrm{p} \leq 0.05$ ). The test conditions included an adsorbent concentration of $50 \mathrm{~g} \mathrm{~L}^{-1}$ and an incubation of 12 hours for the sugarcane and 24 hours for the coconut fibers.

The effect of $\mathrm{pH}$ on the solid-liquid equilibrium can be explained due to electrostatic interaction caused by the change in the surface charge of the adsorbent and the active sites of the dye, where dissociation of the functional groups and the formation of complexes occurs. The increase in the adsorption as a function of the $\mathrm{pH}$ depends on the presence of available counter-ions that retain the desirable species on the surface. For example, at a lower $\mathrm{pH}$, the attached proton can easily adsorb anions, white the inverse behavior occurs at a high $\mathrm{pH}$ due to the hydroxyl groups at the solid/liquid interface[11]. The understanding of the adsorption mechanism can be elucidated through by determining the point of zero charge of the adsorbent. Thus, the 
adsorption of cations is favored at a $\mathrm{pH}$ greater than zero load and the opposite is observed for anions, which was also observed in this study.

For coconut and sugar cane fibers, at $\mathrm{pH}$ values lower than the point of zero charge the surface becomes positively charged, it is expected that the adsorption of the dye is favorable, due to the presence of several functional groups, such as $\mathrm{OH}-, \mathrm{COO}-$ or $\mathrm{SO}_{3}{ }^{2-}$ groups[14-16].

\subsection{Effect of adsorbent concentration on the adsorption of dye}

To assess the effect of the adsorbent concentration on the adsorption of the dye, these assays were done with parameters determined previously, with incubations times of 12 and 24 hours for the sugarcane and coconut fibers, respectively, and both were tested at a $\mathrm{pH}$ of 2 . For both fibers, a significantly higher average of the percentage adsorption was observed when the adsorbent concentration was $20 \mathrm{~g} \mathrm{~L}^{-1}$ (Tukey's test, $\mathrm{p} \leq 0.05$ ) (Figure 3). The observed adsorption percentages for the sugarcane fiber were $97.82 \pm 0.35 \%$ and $94.28 \pm$ $0.60 \%$ for particle sizes of 48 and 65 Mesh, respectively; the observed adsorption percentages for the coconut fiber were $95.22 \pm 0.70 \%$ and $96.54 \pm 0.70 \%$, respectively. Among the particle sizes and the fibers used at this dosage, the highest dye adsorption percentage was observed with the 48 Mesh sugarcane fiber.

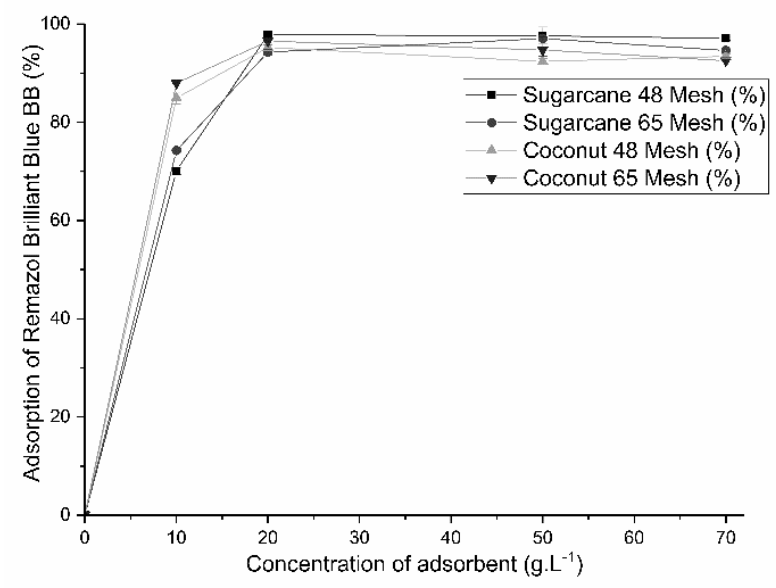

Figure 3: The effect of adsorbent concentration on the adsorption of the dye Remazol Brilliant Blue BB for sugarcane and coconut fibers with grit sizes of 48 and 65 Mesh. Means \pm standard deviation. The test conditions included a time of contact of 12 hours for the sugarcane fiber and 24 hours for the coconut fiber and a pH of 2 for all samples.

Robinson, Chandran and Nigam[13] noted that when using $20 \mathrm{~g} \mathrm{~L}^{-1}$ of corncob as an adsorbent, a higher percentage of adsorption compared was obtained compared with $50 \mathrm{~g} \mathrm{~L}^{-1}$, which was also observed in this study. Increased adsorbent mass promotes a decrease in the adsorption of the dye, which can be explained by two factors. The first is the increase in adsorbent weight in relation to the concentration of dyes and a fixed volume, which leads to the saturation adsorption sites. The second is that the reduction in adsorbent capacity may be due to particle aggregation, which results from the increases mass of adsorbent, and this aggregation leads to reduction in the total adsorbent surface area and an increase in the path of diffusion. Therefore, the mass of the adsorbent used should be sufficient not to occur saturation of assets and not excessive sites to occur aggregation[4-5].

\subsection{Effect on dye concentration on the adsorption of dye}

The effect of the dye concentration on the adsorption of dye was assayed with an incubation time of 12 and 24 hours for sugarcane and coconut fiber, respectively, a pH of 2 and an adsorbent amount of $20 \mathrm{~g} \mathrm{L-1,} \mathrm{pre-}$ viously determined in the assays described above. According to the results (Figure 4), it was observed that with an increasing dye concentration, the percentage of adsorption by the fibers did not significantly decrease. The dye concentrations assayed ranged between 50 and $200 \mathrm{mg} \mathrm{L}-1$, and with a fiber concentration of $20 \mathrm{~g} \mathrm{~L}-$ 1 , the observed adsorption was efficient (more than 90.50\%) and both fibers were effective. By increasing the initial dye concentration, the ability of these fibers to adsorb the dye also increased, probably due to an increase in the concentration gradient. However, at high concentrations, a reduction of the dye adsorption by 
the fiber was observed, probably due to saturation of the adsorption sites5. At the concentrations analyzed, there was a significant decrease, which can be explained by the dye concentration not reaching the maximum saturation of active sites of the fibers. In future studies, increased dye concentrations can be assayed to verify the adsorption effect of by the fibers.

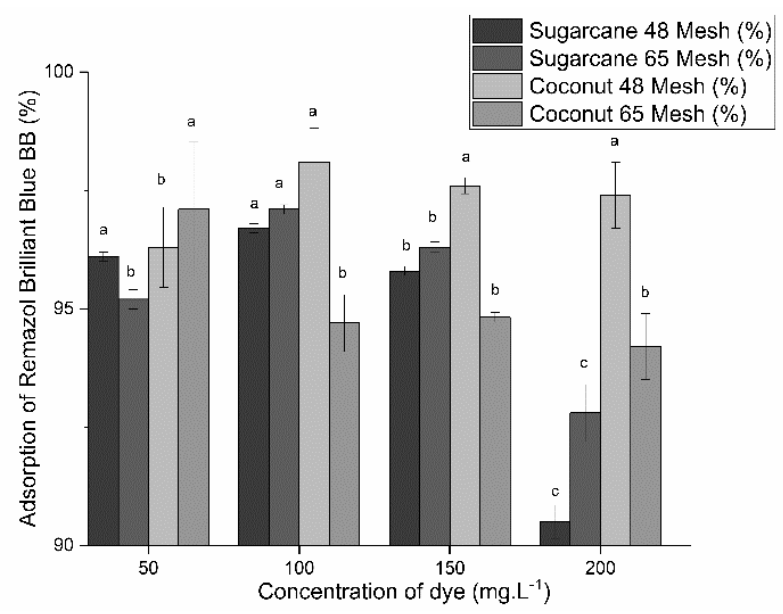

Figure 4: Effect of dye concentration on the adsorption of the dye Remazol Brilliant Blue BB for sugarcane and coconut fibers with grit sizes of 48 and 65 Mesh. Means \pm standard deviation. Different letters for the same dye concentrations indicate significant differences between the samples (Tukey test, $\mathrm{p} \leq 0.05$ ). The test conditions were the time of contact of 12 hours for the sugarcane fiber and 24 hours for the coconut fiber, solution in $\mathrm{pH}$ of 2 and $20 \mathrm{~g} \mathrm{~L}^{-1}$ of fibers for all samples.

\section{CONCLUSIONS}

In this study, the optimal contact time for the adsorption of Remazol Brilliant Blue dye BB by sugarcane and coconut fibers was 12 and 24 hours, respectively, using particle sizes of 48 and 65 Mesh. At a pH of 2, a greater percentage of adsorption for both fibers and particle sizes was observed than at other $\mathrm{pH}$ values. The optimal concentration of adsorbent material was $20 \mathrm{~g} \mathrm{~L}^{-1}$. The effect of dye concentration on the adsorption by these fibers showed that an increase in the dye concentration did not decrease the adsorption for dye concentrations of between 50 and $200 \mathrm{mg} \mathrm{L}-1$. In the experimental conditions used in the study, sugarcane and coconut fibers effectively absorbed Remazol Brilliant Blue dye BB, adsorbing up to $90.50 \%$ of dye. The adsorption process with fibers from lignocellulosic waste could also be studied, as well as its disposal after use in treating textile effluents. In addition, the adsorbent material, such as biomass for industrial boilers, can be studied for desorption and reuse and for use as substrate for cultivating fungi or for other biotechnological purposes.

\section{BIBLIOGRAPHY}

[1] ZHANG, Z., O’HARA, I. M., KENT, G. A., et al., "Comparative study on adsorption of two cationic dyes by milled sugarcane bagasse”, Ind Crop Prod. , v. 42, pp. 41-49, 2013.

[2] AKAR, S. T., ÖZCAN, A. S., AKAR, T., et al., "Biosorption of a reactive textile dye from aqueous solutions utilizing an agro-waste", Desalination, v. 249, n. 2, pp 757-761, 2017.

[3] DEBIAGI, F., IVANO, L. R. P. F. M., NASCIMENTO, P. H. A., et al., "Starch biodegradable packaging reinforced with lignocelulosic fibers from agroindustrial wastes", $B B R$, v. 1 n. 2, pp 57-67.

[4] CARDOSO, N. F., LIMA, E. C., VAGHETTI, J. C. P., et al., "Applications of Brazilian pine-fruit shell in natural and carbonized forms as adsorbents to removal of methylene blue from aqueous solutions-Kinetic and equilibrium study", J Harzard Mater, v. 164, n. 2-3, pp. 1213-1222, 2009.

[5] DENIZ, F., KARAMAN, S. "Removal of an azo-metal complex textile dye from colored aqueous solutions using an agro-residue", Microchemical Journal, v. 99, n. 2, pp. 296-302, 2011.

[6] KADAM, A. A., TELKE, A. A., JAGTAP, S. S., et al., "Decolorization of adsorbed textile dyes by developed consortium of Pseudomonas sp. SUK1 and Aspergillus ochraceus NCIM-1146 under solid state fermentation", J Harzard Mater, v. 189, n. 1-2, pp. 486-494, 2011. 
[7] KADAM, A. A., KULKARNI, A. N., LADE, H. S., et al., "Exploiting the potential of plant growth promoting bacteria in decolorization of dye Disperse Red 73 adsorbed on milled sugarcane bagasse under solid state fermentation", Int Biodeter Biodegr, v. 86, n. 1, pp. 364-371, 2014.

[8] SAFA, Y., BHATTI, H. N. "Adsorptive removal of direct textile dyes by low cost agricultural waste: Application of factorial design analysis", Chem Eng J, v. 167, n. 1, pp. 35-41, 2011.

[9] ZHANG, Z., O' HARA, I. M., KENT, G. A., et al., "Comparative study on adsorption of two cationic dyes by milled sugarcane bagasse”, Ind Crop Prod, v. 42, n. 1, pp. 41-49, 2013.

[10] CARRIJO, O. A., LIZ, R. S. AND MAKISHIMA, N. "Fibra da casca do coco verde como substrato agrícola”, Horticultura Brasileira, v. 20, n. 4, pp. 533-535, 2002.

[11] SATHISHKUMAR, P., ARULKUMAR, M., PALVANNAN, T. "Utilization of agro-industrial waste Jatropha curcas pods as an activated carbon for the adsorption of reactive dye Remazol Brilliant Blue $\mathrm{R}$ (RBBR)", J Clean Prod, v. 22, n. 1, pp. 67-75, 2012.

[12] ROBINSON, T., CHANDRAN, B., NIGAM, P. "Removal of dyes from an artificial textile dye effluent by two agricultural waste residues, corncob and barley husk", J Harzard Mater, v. 28, n. 1-2, pp. 29-33, 2002.

[13] AMIN, N. K. "Removal of reactive dye from aqueous solutions by adsorption onto activated carbons prepared from sugarcane bagasse pith", Desalination, v. 233, n. 1-3, pp. 152-161, 2008.

[14] KHALED, A., NEMR, A. E., EL-SIKAILY, A., et al., "Treatment of artificial textile dye effluent containing Direct Yellow 12 by orange peel carbon”, Desalination, v. 238, n. 1-3, pp. 210-232, 2009.

[15] VIEIRA, A. P., SANTANA, S. A. A., BEZERRA, C. W. B., et al., "Kinetics and thermodynamics of textile dye adsorption from aqueous solutions using babassu coconut mesocarp“, J Harzard Mater, v. 166, pp. 1272-1278, 2009.

[16] SINGH, H., CHAUHAN, G., JAIN, A.K., et al., "Adsorptive potential of agricultural wastes for removal of dyes from aqueous solutions", J Environ Chem Eng, v. 5, pp. 122-135, 2017.

[17] LIN, Q., WANG, K., GAO, M., et al., "Effetively removal of cationic and anionic dyes by pH-sensitive amphoteric adsorbent derived from agricultural waste-wheat straw", J Taiwan Inst Chem E, v. 76, pp. 65-72, 2017.

[18] CRETESCU, I., LUPASCU, T., BUCISCANU, I., et al., "Low-cost sorbents for the removal of acid dyes from aqueous solutions”, Process Safety and Environmental Protection, v. 108, pp. 57-66, 2017.

[19] ADEGOKE, K., BELLO, O. S. "Dye sequestration using agricultural wastes as adsorbents", Water Resources and Industry, v. 12, pp. 8-24, 2015.

[20] KAPDAN, I.K., KARGI, F. "Simultaneous biodegradation andadsorption of textile dye stuff in an activated sludge unit”, Process Biochem, v. 37, pp. 973-981, 2002.

\section{ORCID}

Aline Merci

Maria Inês Rezende

Leonel Vinicius Constantino

Suely Mayumi Obara Doi https://orcid.org/0000-0002-7309-5624

https://orcid.org/0000-0002-6907-5575

https://orcid.org/0000-0001-6254-8328

Não informado 